\title{
Covid 19 Pandemic, Vaccination-Rural, Urban and Religious Perspectives
}

\section{Veena Shenoy*, Sheetal Mahendher, and Shubham Hemani}

ISBR Business School, Bangalore, India

Article Type: Article

Article Citation: Veena Shenoy, Sheetal Mahendher, and Shubham Hemani, Covid 19 Pandemic, Vaccination-Rural, Urban and Religious Perspectives, ISBR Management Journal. 2021; 6(01), 1-4. D0l: 10.52184/isbrmj.v6i1.106

Received date: March 20, 2021

Accepted date: April 25, 2021

*Author for correspondence: Veena Shenoy veena3172@gmail. com $P$ ISBR Business School, Bangalore, India

\begin{abstract}
The purpose of this paper is to understand the ideologies, intent, and reasoning which prompt the millennials to take or shun the vaccine. The study incubates Rural, Urban and Religious sentiments that affect the preferences of inoculation, modify our decision-making process toward mass immunizations, and contribute to vaccine waste in many areas. We hope to convey the fear of not getting the vaccine as well as the elements that encourage folks to immunize themselves for the greater good in this study. Rural approach to vaccine hesitancy is fuelled by rumors, myths - whilst driven by limited access to the outside world. Urban vaccine hesitancy is driven by the abundance of information - giving rise to conspiracy theorists. Religious reluctance to vaccination is driven by notional norms opposing cure by modern treatment.
\end{abstract}

Keywords: Covid19, Pandemic, Vaccination, Covishield, Covaxin, Religious Perspectives

\section{Introduction}

A microbe - the size of a grain of sand has halted human evolution, shut down governments, murdered millions, and triggered unfathomable disasters. March 2020-there was a slew of predictions, some of which predicted an apocalypse. Then came 2021, which brought hope and a cure. A panacea for returning life to normalcy, a rewind after an interminable halt. Just as we thought we'd defeated the adversary, another appeared in the form of vaccination reluctance. Thousands of people are unwilling to participate in vaccination programs due to a variety of concerns, adding to restricted supply and wastage issues in the fight against Covid-19.

\section{Rural Sentiments}

The grim, fragile reality resides in the corridors of the countryside-a treasury of myth and conspiracies. Besides vaccine hesitancy, a plethora of challenges such as digital illiteracy, 
poor smartphone accessibility, and community activism thwart the mass inoculation drives in Rural India.

Pathan, a resident of Janefal village in Maharashtra, roughly a 228-mile drive from Mumbai, read posts on WhatsApp claiming the vaccine dosages are unsafe and that if a doctor administers the shot wrongly, an arm infection may ensue. After that, the only way to save the person is to amputate the limb. The terrified villagers would hear accounts of how immunizations had gone wrong elsewhere-people felt dizzy with fever, some had dysentery, and all perished since the vaccine's adverse effects are not curable with treatment.

Some villagers refused to receive the vaccine because of the concern that if they became sick, they would lose their daily earnings and struggle to make ends meet. There is also a widespread misconception that the government sends low-quality vaccines to villages while providing high-quality vaccines to urban populations. Also, they believe the vaccines can cause heart attacks and is a trap to reduce population pressure.

"Vaccine advocacy, faith-building, and community mobilization" can be the three antidotes for vaccine hesitancy in rural India.

\section{Urban India}

The urban population's perspective towards the vaccine is not astounding either. Yes, people flocking in queues is a soothing site but the perspective is more negative than positive:

- The notion that 'vaccine development takes years before licensing for use by the general public-Pharmaceutical companies, on the other hand, must be speeding up the development of coronavirus vaccine and maybe cutting significant corners in the process, has made the Urban population hesitant.

- When vaccine trials are terminated, such as the AstraZeneca and Oxford University's Covid-19 vaccine, rumor mills fly into overdrive believing that medicine candidates are hazardous for humans

- COVAXIN, India's indigenously developed vaccine, has received mass criticism despite being more effective than its Indian counterpart-thinking it might be below par because it is Made in India

- Contracting the disease even after taking the jab, has risen some doubts about the efficacy of vaccines

- Rare blood clots, heart attacks after being jabbed has sparked controversies

- Partialtowards Pfizer/Moderna vaccines, which has been adopted by Americans as an acme of better efficacy

- When the mortality rate is only $1 \%$, why vaccines?

To fully comprehend vaccines, one must first comprehend that the goal of vaccination is to familiarise the immune system with the alien virus so that when the virus strikes the body, the danger of death is minimal. This approach has allowed for large vaccination campaigns among the urban population. Citizens have lined up for taking vaccines because they believe - 
- It helps curb the spread. In Israel-more than 50\% population has been vaccinated, as a result, the daily caseload is less than 50

- Less than 0.5 percent of people taking vaccines (even just one dose) get infected with the virus

- Mass inoculations help develop herd immunity, critical for taking India back to normalcy

\section{Religious sentiments}

Traditional religious beliefs, according to modernization theorists, tend to weaken when civilizations change from agrarian to industrial economies. Growing prosperity and longer life expectancy may be helping to drive people away from religion, and this global trend has accelerated in the recent decade.

However, in a country with a wide spectrum of caste, creed, religious and spiritual practices-religious sentiments do have an impact on the approach towards vaccination.

Though some religious leaders promote vaccinations-some are reluctant towards injecting alien objects into the body. Following have affected the mindset towards taking the vaccine:

- Rumors fuelling that the vaccines include pork, cow's blood-can lead to impotence and even death

- In the vaccine-lies a chip that tracks daily activities and movements

- One can be prone to terminal illness after months of being vaccinated

- The vaccine can alter our DNA, create homosexual tendencies, and will control our minds to enslave us.

- Vaccines bear the devil mark-will turn us into Satanist

Deliberate collaboration among various stakeholders such as government, civil bodies, religious leaders, celebrities, and influencers can help gain the public's trust in Covid-19 vaccines in the country.

\section{Conclusion}

The Spanish flu of 1918, the H1N1 Virus, or the swine flu epidemic lay down the historical maneuvers or manuscripts to win the battle-masking up, social distancing, and a cure. The cure develops herd immunity-in this case, a vaccination drive to immunize 1.3 billion Indians. In the past, when thousands succumbed to polio, a vaccine led to a sporadic reduction in cases and eventually, normalcy.

Rural, Urban and religious sentiments were even more critical of the cure in the past. Reaching millions was a Hercules task before as well, but a way out was found. The only problem now is - that we have not learned from our past, how the world tackled the deadly health emergencies, how the world moved on, and how we have come back to square one in handling vaccinate hesitancy. 
European Union, the World Health organization, and regulators in numerous countries have cross-checked the efficacy as well as efficiency of the vaccines in circulation. Countries with $75 \%+$ doses administered have seen a shocking reduction in cases, America has approved no masks for those who are fully vaccinated-It is India's time next.

"To fast speed normalcy, we should move on from the religious, urban, and rural hesitancy, reluctance, and conspiracies."

\section{Author Biography}

Ms. Veena Shenoy is an Assistant Professor at ISBR Business School in Bangalore, and a Research Scholar at Surathkal Karnataka, National Institute of Technology. She has 15 years of rich industry and academic experience. Her research interests include behavioral science, cognitive psychology, customer relationship management, and managing human resources. She is a gold medalist from Pune University, India, and has won numerous accolades, such as the best paper awards at international conferences held at institutions of national importance. Mail id: veena3172@gmail.com

Dr.Sheetal Mahendher is an Associate Professor and Head of the Dept of Business Analytics at ISBR Business School Bangalore. She has a vast experience of 22 years in industry and academics. Her areas of interest are statistics, operations research, business analytics. Her special research interest is in the area of Hospital records management. She is a resource person for various workshops on analytics using R, Python, Excel, SPSS, and other software. She has presented and published papers in various journals of repute. Mail id:sheetal.mahen@gmail.com

Mr. Shubham Hemani is currently pursuing PGDM at ISBR business school Bangalore and resides in Kolkata, West Bengal. He had done his graduation from Bhawanipur Education Society College under Calcutta University. His area of interest is Finance as it contributes to holistic growth and crunching numbers. Also, won awards in music, writing, and sports. The zest to work hard and skill enhancement is the aim. Mail id: shubhamhemani13@gmail.com 